\title{
HEARD ISLAND AND THE McDONALD ISLANDS: A WINDOW INTO THE KERGUELEN PLATEAU
}

\author{
by Patrick G. Quilty and Graeme Wheller
}

(with four text-figures)

Quilty, P.G. \& Wheller, G.E., 2000 (30:vi): Heard Island and the McDonald Islands: a window into the Kerguelen Plateau. In Banks, M.R. \& Brown, M.J. (Eds): HEARDISLANDPAPERS. Pap. Proc. R. Soc. Tasm. 133(2): 1-12.

https://doi.org/10.26749/rstpp.133.2.1 ISSN 0080-4703. School ofEarth Sciences, University ofTasmania, GPO Box 252-79, Hobart, Tasmania, Australia 7001 (PGQ); Volcanex International Pry Ltd, Suite 4, 286 Macquarie St, South Hobart, Tasmania, Australia 7004 (GW).

The modern phase of volcanism on Heard Island probably is younger than one million years and is responsible for building Big Ben, the bulk of the island. The nearby McDonald Islands are less than 100000 years old and are volcanically active. Big Ben sits on the Drygalski Formation, a Late Miocene-Early Pliocene volcanic/marine sediment with glacial influence, which occurs as a generally flat-lying, cliffforming unit over most of Heard Island. The "basement" of Palaeogene limestone crops out mainly on Laurens Peninsula but also sporadically beneath Big Ben and occurs as clasts in volcanics. Historical eruptions of Heard Island, most recently from 1985 to at least 1992 and probably later, have occurred from Mawson Peak, the summit cone built upon Big Ben, but young lavas and ash cones are widespread around the island. Recent volcanic activity is summarised.

Heard Island and the McDonald Islands, with the Kerguelen Islands, are exposed parts of the Kerguelen Plateau, possibly the largest submarine plateau on earth, and provide geochemical and isotopic insights inro the formation of oceanic plateaux, mantle plume development and the separation of Australia, India and Africa from Antarctica. The Plateau has a complexhistory that commenced with subaerial basaltic volcanism at $115 \mathrm{Ma}$, about 10 million years after India and Antarctica separated. It sank below sea level in the midCretaceous, and subsided to its present setting as Broken Ridge and Kerguelen Plateau separated at 43 Ma when the Southeast Indian Ridge came between Australia and Antarctica. It is likely that, during its entire existence, some part of the plateau has been volcanically active, yielding a long-term geochemical record of large-scale crust-mantle evolution.

Key Words: Heard Island, McDonald Islands, Kerguelen Plateau, volcanism, volcanic activity, Big Ben, Laurens Peninsula, plume systems

\section{INTRODUCTION}

The Australian Territory of Heard Island and the McDonald Islands, centred on Heard Island at $53^{\circ} 06^{\prime} \mathrm{S} ; 73^{\circ} 32^{\prime} \mathrm{E}$, is one of the most isolated regions on Earth, lying in the centralsouthern Indian Ocean. Its closest neighbour is the French Kerguelen Islands, approximately $466 \mathrm{~km}$ to the northwest. The Territory hosts Australia's highest mountain (Big Ben $-2750 \mathrm{~m}$ ) and, with the Kerguelen Islands, is the only exposed part of the Kerguelen Plateau (fig. 1), possibly the largest submarine plateau on Earth. Volcanic activity has been a feature of the region over approximately 115 million years, and Big Ben, the current mildly active volcano on Heard Island, has a history of perhaps less than one million years (Clarke et al. 1983). The McDonald Islands are low basaltic islands about $54 \mathrm{~km}$ west of Heard Island. The area was accepted in 1997 for inscription on the World Heritage List based on its geologically unique features.

This paper summarises the known geological evolution and significance of Heard Island and the McDonald Islands as a background to other studies on the biology, environmental value, and management requirements for the region.

\section{PREVIOUS STUDIES}

It is uncertain who first saw Heard Island. It was seen and recorded by Peter Kemp from Magnet in November 1833 and by the whaler Thomas Long in 1849. John Heard and his wife Fidelia, sighted the island in November 1853. Captain McDonald, early in 1854, discovered the islands now bearing his name. There were other sightings in 1854 and 1855. Erasmus Darwin Rogers of Corinthian made the

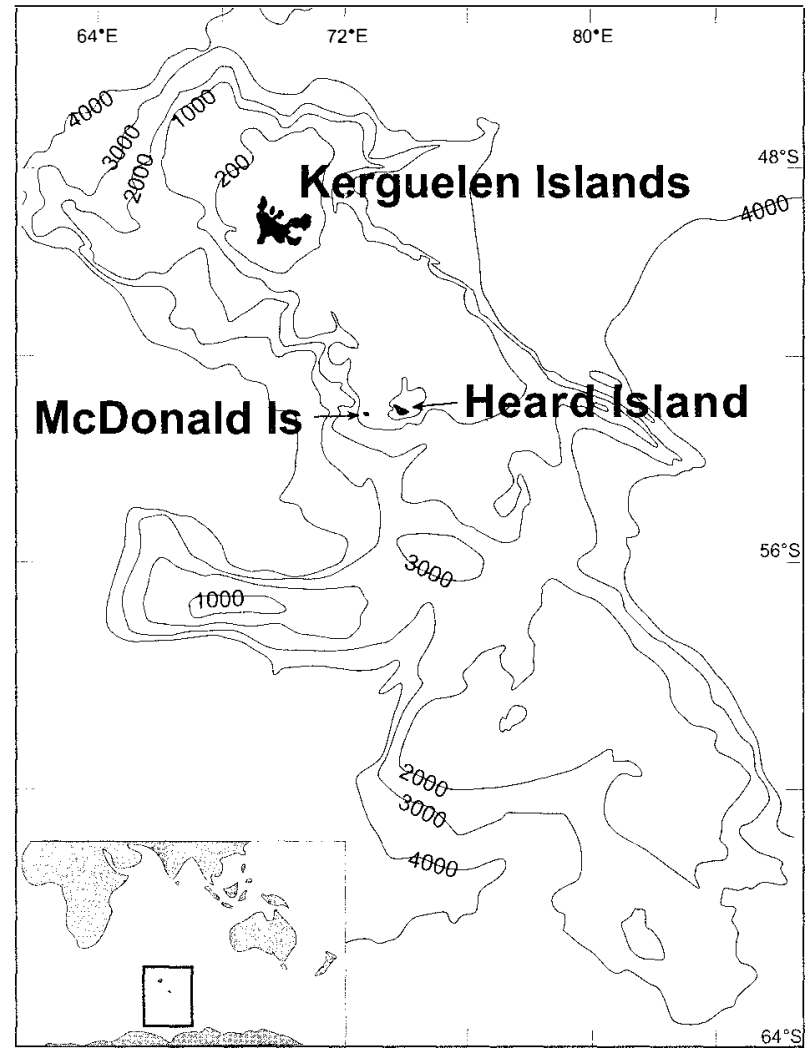

FIG. 1 - Kerguelen Plateau and its main geomorphic features. 
first landing in March 1855 . He returned soon after and began sealing operations which flourished until 1888 .

The British did not name the island for Heard but the name was popular (under various spellings) with the sealing community and it became respectable by usage. Although originally claimed for Britain, it was transferred to Australia by "exchange of notes" on 19 December 1950 and Australia formally assumed responsibility in 1953.

The pioneering accounts of the geology of Heard Island were described by Tyrell (1937) following Sir Douglas Mawson's 1929-31 British-Australian-New Zealand Antarctic Research Expedition (BANZARE) (Mawson 1932). Tyrell described in detail the petrology of 35 samples collected by BANZARE in November 1929 and recounted three earlier scientific visits to the island. The first was on 5 February 1873 by the British Challenger expedition. The reports of this expedition published in 1885 included brief mentions of the volcanic rocks in the Atlas Cove area. In 1889, Renard described several basaltic rock types collected by the Challenger Expedition as having varying amounts of plagioclase, augite and olivine (in Tyrrell 1937).

The second visit was by the 1901-3 German Gauss Expedition for seven hours on 3 February 1902. A geologist of the expedition, E. Philippi (1908), gave a geological description of the Rogers Head area including the observation of Globigerina limestone clasts among the material ejected from some young ash cones (in Tyrrell 1937). A petrological study of Philippi's samples by Reinisch (1908, in Tyrrell 1937), incorporating several chemical analyses, revealed various basaltic rock types, including limburgites, as well as trachytes. A further analysis of a sample from the Challenger Expedition was presented by Lacroix in 1923 (in Tyrrell 1937).

The third early scientific visit was by French geologist $\mathrm{E}$. Aubert de la Rue for eight days in 1929. He collected many basaltic and trachytic samples from the Rogers Head-Cave Bay area and reported that "immense plumes of smoke" emanating from the summit had been observed in 1910 by Captain Hobart Seymour, commander of the Wakefield.

The first substantial reports of the geography and geology of Heard Island were by Lambeth $(1951,1952)$, who was a geologist member of the first Australian National Antarctic Research Expedition (ANARE) which visited the island for a year from December 1947. These were followed by observations made by Stephenson (1964) during an unsuccessful first attempt at climbing Mawson Peak, the summit of Heard Island. Stephenson spent six weeks on the island early in 1963 and collected about 80 samples, from which geochemical and palaeomagnetic data were reported (Stephenson 1972, Irving et al. 1965). Clarke et al. (1983) reported geochemical, Sr isotope and K-Ar age data, including the first analyses of volcanic rocks from the McDonald Islands. Clarke visited Heard and McDonald Islands for a few days in March 1980 as part of a National Mapping expedition to the islands and his samples are housed at Monash University.

Geologists J. Barling and G. Wheller spent two months on the island as part of the helicopter-supported 1986-87 Heard Island ANARE. They collected mainly volcanic samples from all parts of the island and flew several times over Mawson Peak, including one landing, to observe summit crater activity. Their samples are housed at Monash University and the University of Tasmania. The major isotopic and petrological results of this visit were reported by Barling et al. (1988), Barling \& Goldstein (1990),
Barling et al. (1994) and Hilton et al. (1995). Some samples used in these studies, in addition to those obtained by Stephenson and Lambeth, were obtained by the BluntVining Expedition which successfully climbed Mawson Peak in 1983 (Barling 1990a,b)

\section{DESCRIPTION}

Heard Island (fig. 2) is $43 \mathrm{~km}$ long from Laurens Peninsula in the northwest to the end of Elephant Spit in the southeast. The main body of the island is central, approximately circular and slightly less than $20 \mathrm{~km}$ in diameter. This marks the base of the main feature of the island - the historically mildly active volcano of Big Ben with Mawson Peak $(2750 \mathrm{~m}$ ) at its centre. Laurens Peninsula is also roughly circular, about $6 \mathrm{~km}$ in diameter and has another distinct volcano, $\mathrm{Mt}$ Dixon $(706 \mathrm{~m})$, at its summit, $19 \mathrm{~km}$ from Mawson Peak. Mt Dixon appears to be a very fresh volcano which formed within the last 10000 years but has not been observed active. Radial lava flows are very clear and two flows in particular are unvegetated and probably less than a few hundred years old. Small ash cones and related lava flows also occur in places close to the coast around the island. Elephant Spit is a sand spit some $10-12 \mathrm{~km}$ long, extending east from the island and composed of glacial and fluvial debris carried east by current activity. It is sometimes cut by the sea and varies in form.

The basement of Heard Island, visible best around the southern margin of Laurens Peninsula, consists of weakly to strongly indurated Palaeogene limestone, folded at some stage and now inclined at a variety of dips. The surface was planed before the deposition about 4-10 million years ago of a blocky horizontal rock unit - the Drygalski Formation - which contains evidence of shallow marine conditions and volcanic and glacial influences. It forms a solid unit of roughly uniform thickness. It, in turn, was planed before the Big Ben volcano was formed, over the last one million years.

The island is heavily glaciated with glaciers radiating from Mawson Peak and on Laurens Peninsula. The age of the oldest ice on the island is not known but estimated to be approximately 100 years. Glaciers have been in marked and documented retreat (Lambeth 1951, Ruddell \& Allison 1997 , Budd 2000) since the occupation of the island in 1947.

Heard Island is marked by unusually well-developed buttresses radiating from the main peak and separating individual glacial valleys. They probably owe their origin to the effects of erosion by radial glaciers, ordinary avalanches in fragmental volcanic sediments, and major debris avalanches. They are lacking in the southwestern sector.

The history of the island and its volcanoes has not been fully documented. Mawson Peak is a small, classical volcanic cone sitting as a distinct entity on a plateau on the top of Big Ben, with a southwestern face reaching the sea with an uninterrupted uniform slope. To its north, east and southeast, it is surrounded by a scarp which marks the position of a debris avalanche amphitheatre. Formidable ice-cliffs surround the plateau on its northern and eastern sides. The upper part of Big Ben appears to have slumped to the southwest and the current, considerably younger, small volcano has rebuilt inside the resulting landslide scar.

About $45 \mathrm{~km}$ west of Laurens Peninsula lies McDonald Island which appears to have been visited only twice by humans and, thus, has value because it appears pristine. 


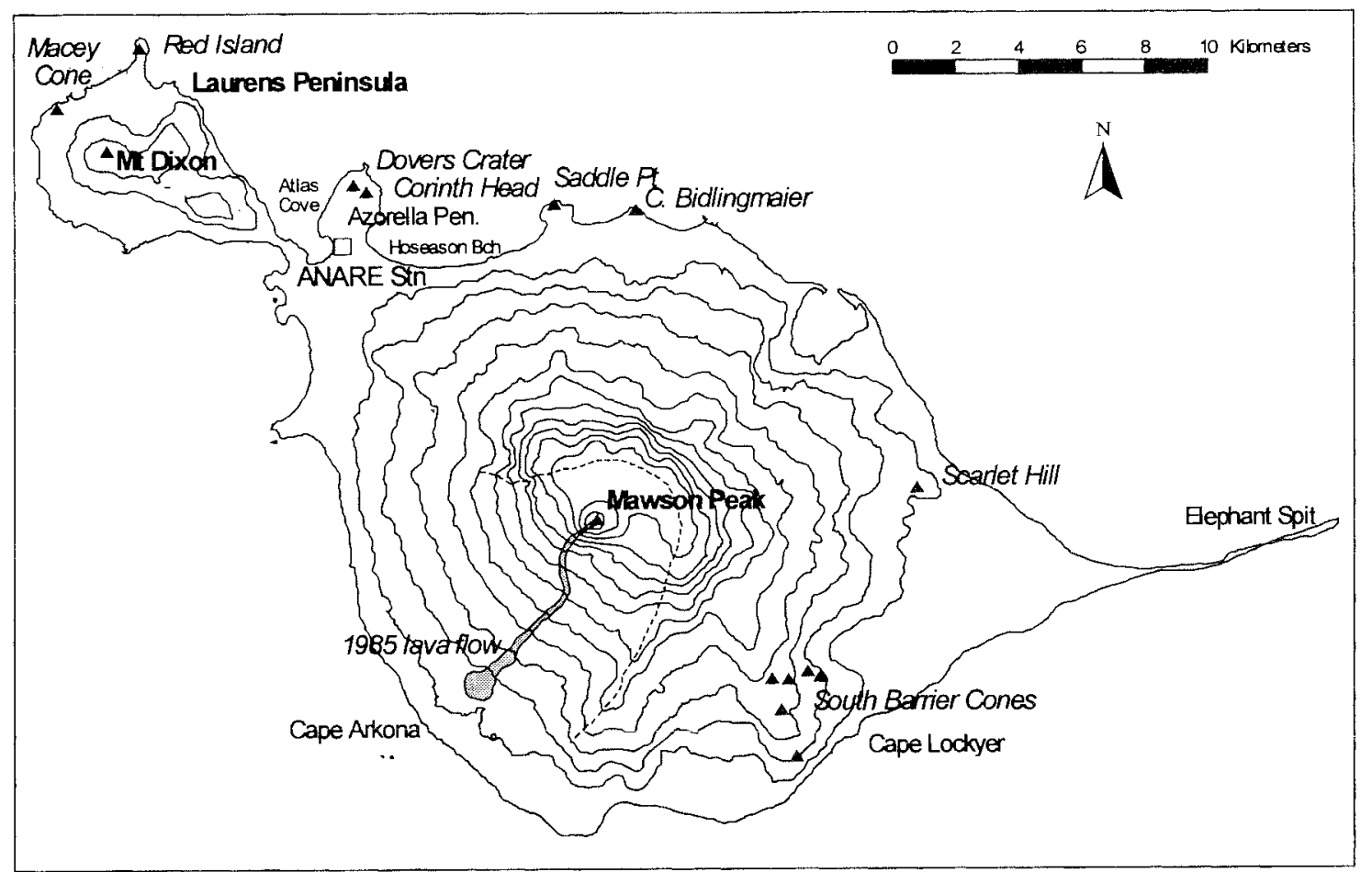

FIG. 2 - Locations on Heard Island mentioned in the text.

Until recently, it was thought to have been evolved over the last 100000 years (Clarke et al. 1983) with the youngest known lavas of about 35000 years. The island is composed of a phonolitic lava, which is very different from the basanitealkali basalt-trachyte series which characterises Heard Island and includes feldspathoids. In 1992, pumice in large quantities washed up on Heard Island but is identical in composition to the rocks composing McDonald Island (J. Sheraton, pers. comm., 10 June 1993; Collerson et al. 1998). Similar pumice from the head of Atlas Cove was analysed by Tyrrell (1937, Table X, sample 10). The presence of fresh pumice was initially taken as evidence of a submarine eruption in the area (Quilty 1995); however, in March and April 1997, active steam plumes were seen at the northern end of McDonald Island, suggesting that a subaerial eruption may have occurred in this area.

Interestingly, fresh pumice on Heard Island also occurs on higher elevations (Stephenson 1964) and in a primary bed a metre thick under thin moraine at Spit Bay. These pumices are trachytic and essentially identical in composition to the trachytic lavas around Laurens Peninsula (Stephenson 1964, Barling et al. 1994, Wheller pers. obs.). Their source is unknown although it is probably in the high parts of the Laurens Peninsula where the trachytic lavas are concentrated.

Shag Island and two other small islets lie about $9 \mathrm{~km}$ north of Heard Island and are other emergent, though unstudied, outcrops.

\section{ORIGIN AND EVOLUTION OF KERGUELEN PLATEAU}

The history of Kerguelen Plateau (fig. 3) was investigated by Ocean Drilling Program (ODP) Legs 119 and 120 in 1988, and Leg 183 in 1999. The Kerguelen Islands are more complex than Heard Island, because of their longer history (fig. 4) and great differentiation of lava types (Nougier \& Thomson 1990).

Royer \& Coffin (1992) and Fitzgerald (1999) reviewed the tectonic evolution of Kerguelen Plateau. By the Aptian (119 Ma), India had been separated from Antarctica for some 13 million years but no part of Kerguelen Plateau existed. By 110 million years (Albian), India had moved north about $10^{\circ}$ of latitude from Antarctica and the basic structure of Kerguelen Plateau (including what is now Broken Ridge) had formed by subaerial extrusion of a large number of basaltic lava flows ("excessive volcanic activity" on a mid-ocean ridge - Munschy et al. 1992) in a Large Igneous Province (LIP). By 84 million years (Santonian), India had moved away as a mid-ocean ridge came between northern Kerguelen Plateau and India. For the next 40 million years, until the mid-Eocene, development in the Indian Ocean was mainly along this NE-SW trending ridge. In the mid-Eocene ( $43 \mathrm{Ma}$ according to Munschy et al. 1992), there was a marked change as a new spreading ridge split the Kerguelen Plateau/Broken Ridge complex into its modern components. Thereafter, Kerguelen Plateau was an independent entity and characterised by volcanism at its northern end (Munschy et al. 1992). One of the major questions about the Plateau is whether it is purely oceanic or has some continental influence in its origin and history (Watkins et al. 1974).

The tectonic history also controlled the change from subaerial to marine deposition and subsequent water depth. The Aptian lavas were weathered to form red soils in which grew forests of conifers (Podocarpoxylon) that were affected by forest fires, possibly initiated by volcanism (Francis $\&$ Coffin 1992). Palynology (Mohr \& Gee 1992) indicates abundant terrestrial vegetation until the Late Cenomanian $(92 \mathrm{Ma})$. Much of Kerguelen Plateau sank below sea level near the Turonian/Cenomanian transition and underwent 

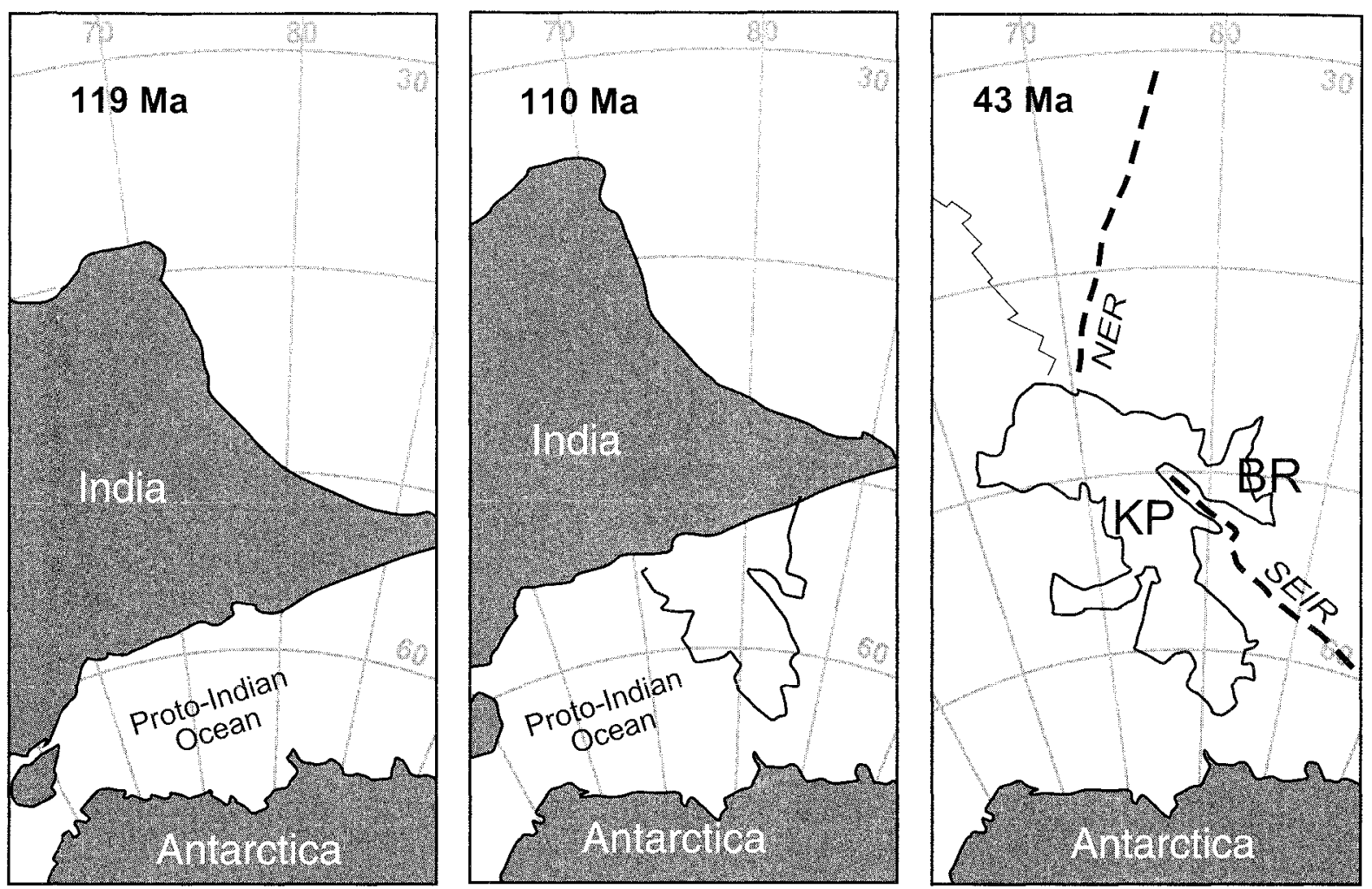

FIG. 3 - The evolution of Heard Island and of Kerguelen Plateau at 119, 110 and 43 Ma (after Royer \& Coffin 1992). NER - Ninetyeast Ridge; SEIR - Southeast Indian Ridge; KP - Kerguelen Plateau; BR - Broken Ridge.

deposition of carbonate sediments dominated by the remains of various microfossils, especially foraminifera and calcareous nannoplankton.

Throughout the history of the Plateau (fig. 4), over 115 million years, it is likely that vegetated islands have stood above sea level. Volcanism probably was active through all this time somewhere on the Plateau.

\section{SUCCESSION ON HEARD ISLAND}

The most prominent volcano on Heard Island is one million years old or less (Clarke et al. 1983) and sits on a complex basement. The history is poorly known and no proper geological map of the island exists.

Two broad intervals of island history are apparent. The first involves the dominantly carbonate sediments that constitute the dipping basement. The latter consists of three volcanic phases.

\section{Palaeogene "Basement" of Heard Island}

In places near sea level on both sides of the eastern Laurens Peninsula, in small areas around Big Ben behind Hoseason Beach, and on the eastern side of Azorella Peninsula near Corinth Head, the Laurens Peninsula Limestone (Lambeth 1952) crops out unconformably beneath the Drygalski Formation. The limestone consists mainly of thinly bedded, generally light-coloured, nanno oozes of unknown thickness which contain planktonic foraminifera and calcareous nannofossils, together with less common argillaceous limestone containing miospores and dinoflagellates.
The disposition of clasts suggests that the limestone is everywhere close to sea level. It forms the "basement" of the island and is part of the carbonate succession studied on Kerguelen Plateau by the activities of ODP Legs 119, 120 and 183.

Ages of "lower Tertiary" (Glaessner in Lambeth 1952), and Late Paleocene, Eocene and Oligocene (Quilty et al. 1983) have been recorded but can be refined if fresh, less lithified material can be obtained. Material studied to date has been highly lithified with stylolites common, suggesting significant depth of burial or tectonic pressure. Lambeth (1952) refered to "thin soft tuffaceous shales" in the sequence indicating the existence of non-lithified material. Stephenson (1964) believed that the dips resulted from faulting or intrusion rather than the compression that Lambeth favoured. More information about coeval vegetation may be gained from study of darker sediments in the sequence that may contain a palynological record. The only indication of the thickness comes from ODP drilling ( $70 \mathrm{~m}$ of Palaeogene carbonate at Site 747 ; Schlich et al. 1989).

After deposition, these pelagic sediments were tilted to some $25-35^{\circ}$ with an east-west strike, but neither cause nor the timing are documented. It may relate to separation of Kerguelen Plateau and Broken Ridge at $43 \mathrm{Ma}$ (Munschy et al. 1992). Since it was tilted, the limestone has been planed by erosion to produce a gently south dipping surface which is about $75 \mathrm{~m}$ a.s.l. on southern Laurens Peninsula.

These sediments accumulated in open ocean, sometimes cool, conditions. The foraminiferal faunas contain small, thin-walled globigerinid forms and lack diversity. While cool, there is no indication of glacial conditions. 


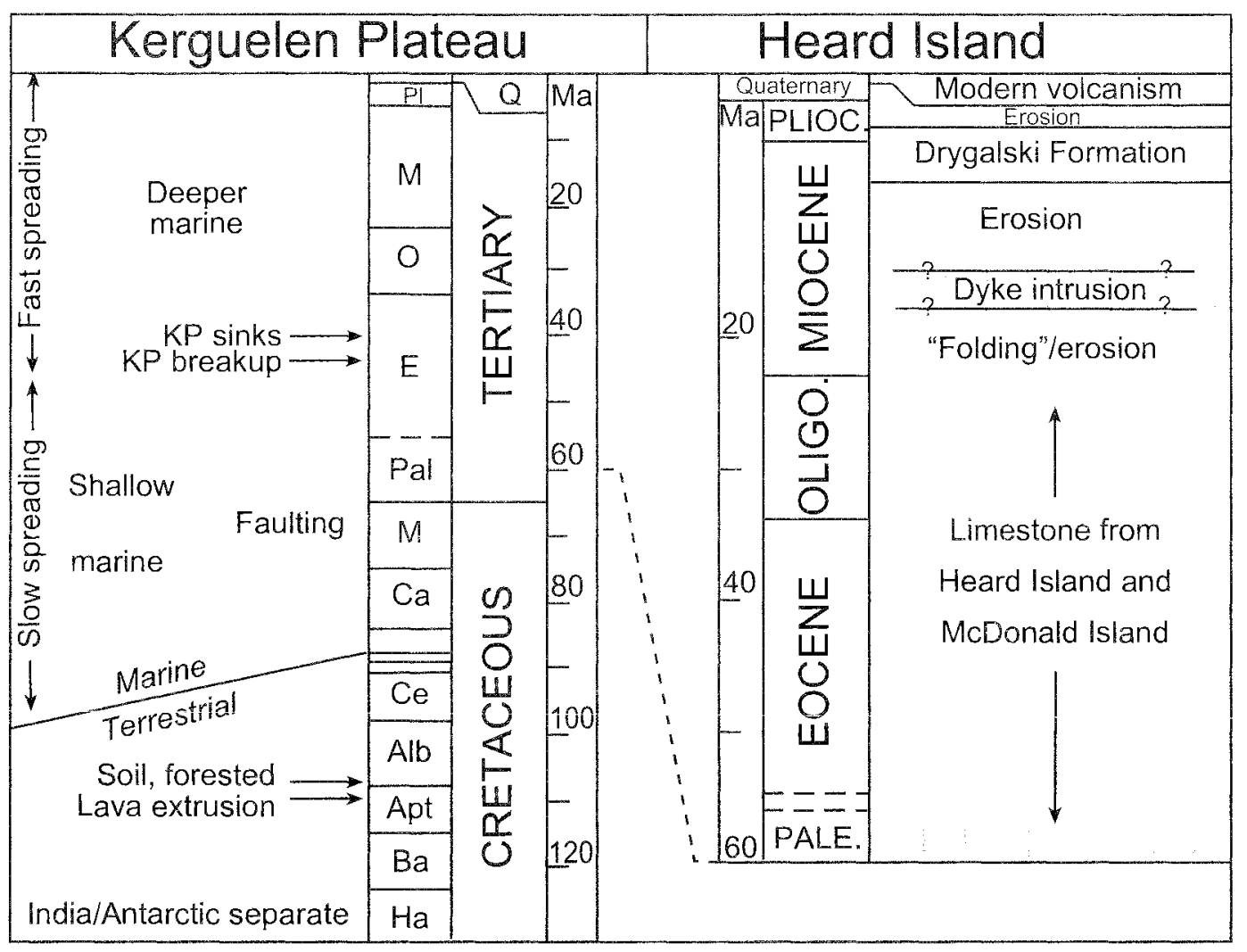

FIG. 4 - Stratigraphy and history of Kerguelen Plateau and Heard Island.

\section{Miocene/Pliocene Volcanism}

The first phase is no older than Late Miocene and is represented by intrusives into the limestone basement (Stephenson 1964, Clarke et al. 1983). Behind Hoseason Beach, the intrusion is about $30 \mathrm{~m}$ thick

The second phase is Late Miocene-Early Pliocene and these basaltic volcanics were erupted during glaciation to form the Drygalski Formation of conglomerate/sandstone/ mudstone. The Drygalski Agglomerate or Formation is one of the main rock units on Heard Island and crops out around the island as a solid, blocky, cliff-forming formation. Called the Drygalski Agglomerates by Lambeth (1952) and the Drygalski Formation by Clarke et al. (1983), it consists of volcanolithic breccia, hyaloclastite, pillow lava and tillite. It is generally horizontal, but in places basaltic sills and dykes and dioritic stocks, cause local deformation. The sequence is exposed in cliffs up to $200 \mathrm{~m}$ high along the northern and eastern coasts, and beneath the South Barrier on the south coast. Its base overlies the Palaeogene limestone with a $35^{\circ}$ unconformity surface (Lambeth 1952), and the top forms a flat upper erosional surface.

The Drygalski Formation needs detailed study to define its age, origin, palaeoenvironment and structure. Stephenson (1964) made comprehensive observations which indicate it is up to $300 \mathrm{~m}$ thick (Lambeth 1952 suggested $350 \mathrm{~m}$ ), but thickness varies. Massive and pillow lavas indicate submarine volcanism and it may be glacial in part, based on the presence of striated boulders. Fleming (1957) described the bivalve Chlamys heardensis from this unit and Quilty et al. (1983) recorded a few fossils from near Cape Lockyer.

During deposition of the Drygalski Formation, the geography of the region was different from the modern.
Stephenson (1964) believed some of the Drygalski Formation came from nearby emergent land to the north.

\section{Quaternary Volcanism on Heard Island}

The final phase of volcanism produced the two landforms that dominate modern Heard Island, Big Ben and the Laurens Peninsula area. The products are dominantly lavas with little ash apart from that forming small satellite ash cones in various places around the coast. A primary trachytic pumice deposit about a metre thick occurs ncar Spit Bay, overlain by a thin moraine deposit, and Stephenson (1964) reported abundant angular pumice clasts on Mt Drygalski and Mt Aubert de la Rue. Clarke et al. (1983) regarded the history of this phase of volcanism as being unlikely to extend beyond $1 \mathrm{Ma}$ ago, based on K-Ar age dating of lavas and general morphology.

Overall, the lavas are mainly highly porphyritic basanites (limburgites and ankaramites), alkali basalts and trachybasalts. They contain abundant and large phenocrysts of clinopyroxene, typically strongly zoned, and olivine with lesser amounts of plagioclase, titanian magnetite and ilmenite phenocrysts in glassy or holocrystalline groundmasses. Sparsely porphyritic trachytic rocks occur mainly on the Laurens Peninsula area, forming the major landforms of the area, including the remnant crater of Cave Bay, and underlying the younger basaltic flows erupted from $\mathrm{Mt}$ Dixon. Compared to the basalts, the trachytes contain kaersutite and biotite, less clinopyroxene, titanian magnetite and ilmenite, more plagioclase, and only rare olivine. The trachytic sequence appears to have been rapidly uplifted prior to the Mt Dixon basaltic volcanism, possibly as a 
result of the emplacement of a shallow cryptodome which is yet to be revealed by erosion (Barling 1990a, b).

\section{HOLOCENE VOLCANIC FEATURES}

Many young volcanic features, which have not been described in detail previously, are present on Heard Island. The following observations result largely from fieldwork by Wheller during the 1986-87 Heard Island ANARE.

\section{Big Ben Group}

\section{Mawson Peak}

In January 1987, the summit of Mawson Peak contained a cylindrical crater $40-50 \mathrm{~m}$ across and $50-70 \mathrm{~m}$ deep that was not observed during two earlier successful ascents of Mawson Peak. In 1965, the first party reported seeing only a deep furrow $25 \mathrm{ft}$ deep, $75 \mathrm{ft}$ across and $250 \mathrm{ft}$ long. The second party, in 1983, saw a rocky area from which steam was being emitted. The crater, therefore, probably formed as a result of a 1985 eruption. Between December 1986 and January 1987, during the 1986-87 Heard Island ANARE, observations from helicopter revealed that the crater contained a lava lake with a black ropey surface which periodically opened to reveal red molten lava. An Army Alpine Association climbing parry which reached the summit in January 2000 reported seeing "a large vent about $10 \mathrm{~m}$ long with smoke billowing out continuously" (Wheller pers. comm.).

Mawson Peak sits in a semicircular plateau bounded to the north and east by a pronounced ridge rising 100 $200 \mathrm{~m}$ above the plateau and, from each side of the plateau, the flanks of Big Ben extend almost to sea level. The smooth southwest sloping surface, $5 \mathrm{~km}$ wide at its top, between the flanking ridges (Allison Buttress and Holmes Ridge) is markedly distinct from the rugged topography of the other parts of the flanks of Big Ben and is suggestive of a large-scale landslide - a debris avalanche. Stephenson (1964) suggested that the summit is a caldera, indicating an origin by volcanic collapse, but an origin by slumping into the sea of a large part of Big Ben, including its original summit, seems more likely. Mawson Peak has subsequently grown by the eruption of volcanic material near the top of the slump, probably close to the site of the earlier summit. The seafloor southwest of the island has not been charted properly but is shallower than that around other parts of the island, probably reflecting the site of debris from the volcano.

The 1985 lava probably formed when magma filled the crater and spilled over through a deep notch on its southern side. It flowed down the southwest of Mawson Peak along a sigmoid path about $8 \mathrm{~km}$ long through the glacial ice, terminating in a narrow ice valley $70-100 \mathrm{~m}$ wide and 20-30 $\mathrm{m}$ deep about $450 \mathrm{~m}$ a.s.l. and $3 \mathrm{~km}$ from the coast. The lava flow surface is slightly spinose but generally smooth with a copper-coloured sheen. Pahoehoe and ropey patches up to a few metres across are common. "Entrail" pahoehoe also occurs in places where lava flowed over large, earlier lava blocks.

The lava is highly vesicular and coarsely porphyritic, comprising about $10 \%$ phenocrysts of olivine, clinopyroxene and rare titanian magnetite in a holocrystalline basaltic groundmass of plagioclase, clinopyroxene and ilmenite microlaths and titanian magnetite microprisms. Olivine phenocrysts are smaller but more abundant than those of clinopyroxene and are generally subhedral and unzoned, except for slight marginal zoning. A few show undulose extinction and many contain small inclusions of chromian spinel and brown glass. Clinopyroxene phenocrysts are generally subhedral, in places occur in glomerocrysts, display complex oscillatory zoning and contain inclusions of brown glass and chromian spinel. (Wheller, pers. obs.).

\section{Azorella Peninsula}

Azorella Peninsula is a low headland about $2 \mathrm{~km}$ wide and $3 \mathrm{~km}$ long to the northwest of Big Ben. It is built mainly of thin basanitic and basaltic flows, exposed in the cliffs forming the edges of the peninsula. At least the uppermost flow emanated from a $100 \mathrm{~m}$ high composite cone forming the southwestern shoulder of Corinth Head. This unnamed, flat-topped cone possesses a partly infilled summit crater about $30-40 \mathrm{~m}$ wide and there are several small subsidiary craters on its western side. Thin layers of scoria and lava are exposed in the summit crater walls.

Although moderately vegetated the uppermost lava appears young and covers most of the peninsula. It is moderately vesicular and coarsely porphyritic, comprising about $20 \%$ phenocrysts of subhedral olivine and much less abundant clinopyroxene in a hyalocrystalline groundmass containing clinopyroxene microprisms. Some larger olivine phenocrysts are partly rounded and embayed with undulose extinction. Many contain small chromian spinel inclusions. Except for its southern margin the lava extends to the edges of the peninsula where it has been truncated by the continuing marine erosion. It is bounded on its southern side by volcanolithic sandy moraine. Small lava tunnels, striking westwards, and collapsed tumuli occur in the northern part of the peninsula.

Eroded remnants of trachytic pyroclastic volcanics of ash cones on Azorella Peninsula are evidence of a period of pyroclastic volcanism which predates at least the uppermost lava flow, and may once have formed parts of the same large complex cone, almost all of which has been destroyed by glacial or marine erosion. Each remnant - Rogers Head, Corinth Head and Balanced Rock - is constructed of thin-layered, well-sorted, medium-grained, leucocratic tuff, partly comprising abundant olivine and clinopyroxene crystals, and dips at about $30^{\circ}$ to the west and southwest, indicating that the main part of the cone lay off the present northeast margin of Azorella Peninsula. Prominent disconformities are exposed in the tuff sequences, indicating marked shifts in pyroclastic activity during deposition.

Dovers Crater is a small basaltic scoria cone in the western part of the peninsula. It is mantled by a thin-layered $0.5 \mathrm{~m}$ thick deposit of leucocratic olivine- and clinopyroxenebearing tuff. The deposit contains abundant basaltic lava blocks up to about $0.3 \mathrm{~m}$ across. Many of these lie in deep sags in the underlying tuff, indicating that they were deposited as ejecta coevally with the tuff. Small limestone clasts are also present but less abundant than the basaltic blocks.

\section{Saddle Point}

Saddle Point consists of a small composite ash ridge about $40-50 \mathrm{~m}$ high and $100 \mathrm{~m}$ long, and associated basaltic lava flow joined to Big Ben by a small, low-lying sand plain. A large part of the ridge has been destroyed by encroaching marine erosion but a deep, well-formed summit crater about 
$30 \mathrm{~m}$ across, surrounded by lava spatter, remains at its western end. The highest point lies $107 \mathrm{~m}$ a.s.l.

The lava is moderately vegetated and its northern side has been truncated by marine erosion. It is moderately vesicular and coarsely porphyritic, comprising about $10 \%$ phenocrysts of olivine and much less abundant clinopyroxene in a hyalocrystalline groundmass containing clinopyroxene and plagioclase microprisms, ?titanian magnetite granules and ilmenite laths. Olivine phenocrysts vary widely in size, contain small glass and chromian spinel inclusions and are generally subhedral, with some rounded and embayed. Rare large crystals show undulose extinction and strong marginal zoning. Clinopyroxene phenocrysts are mostly euhedral and generally smaller than those of olivine. Larger crystals display mottled interior zoning and broad oscillatory-zoned rims.

\section{Cape Bidlingmaier}

Cape Bidlingmaier is also a small volcanic headland on the northern side of Big Ben. It consists of a series of basaltic lava flows, exposed in sea cliffs formed as a result of encroaching marine erosion, and a well-formed but partly eroded ash cone. The summit of the cone is $120 \mathrm{~m}$ a.s.l. Lava spatter and small spherical bombs are common around the summit area. An unusual feature of the cone is that its southern flank is entirely covered by a prominent moraine which just extends into the summit crater. The cone, and its associated lavas, are older than the last glacial maximum on Heard Island.

The uppermost lava flow on Cape Bidlingmaier is ropey basalt, moderately vegetated, and markedly different from the other young lavas around Big Ben. It is lightly vesicular and finely porphyritic, comprising about $5 \%$ small euhedral phenocrysts of olivine, clinopyroxene and titanian magnetite in a holocrystalline groundmass of plagioclase microlaths and clinopyroxene and titanian magnetite granules. A few larger, embayed olivine phenocrysts are also present, and both they and the euhedral olivine phenocrysts contain small chromian spinel inclusions.

\section{Scarlet Hil}

Scarlet Hill consists of a prominent red scoria cone with broad summit crater lying over a narrow, flat-topped and steep-sided rampart on the northeast flank of Big Ben. The southern side of the rampart has been eroded by glacial activity and the summit crater is open towards the south. A small tongue of lava lies on the eastern flank and another small flow extends from beneath the eastern side to the edge of the northern cliff face of the rampart and onto the scree slope below. This lava clearly formed after erosion, during a period of glaciation more intense than the present, which formed the northern side of the rampart. It is finely vesicular and coarsely porphyritic, comprising about $15 \%$ phenocrysts of olivine and clinopyroxene in a hyalocrystalline groundmass containing scattered plagioclase microlaths and clinopyroxene microprisms. Olivine and clinopyroxene phenocrysts are approximately equally abundant. Olivine phenocrysts are mostly subhedral, with some rounded and embayed, and contain small glass and ?chromian spinel inclusions. Some clinopyroxene phenocrysts are euhedral and display strong oscillatory zoning; others are rounded and embayed with internal melt zones and show complex mottled zoning.

\section{South Barrier}

The South Barrier is a major escarpment extending for $7.5 \mathrm{~km}$ from the eastern side of the summit ridge of Big Ben to the coast. Behind its lower part, there is a broad plateau bearing three well-formed scoria cones and at least two mappable young lavas. The remains of a fourth scoria cone lie at the southwestern corner of the plateau. Half of this prominent red cone has been destroyed by coastal erosion. While the summit of the eroded cone is missing, the three complete cones possess deep summit craters, two of which comprise two distinct sub-craters. The existence of the cones was first noted by Stephenson (1964), who observed them during an unsuccessful attempt to climb to the summit of Mawson Peak.

The youngest lavas lie on the western and eastern sides of the plateau. The eastern lava flowed southeast, at least as far as the southern and eastern margins of the plateau where it has been truncated by erosion, and is virtually unvegetated; however, the absence of vegetation probably results from very harsh climate more than the recent age of the flow, which is dull grey in colour, blocky and does not appear to be very young although petrographically very fresh. It is moderately vesicular and coarsely porphyritic, comprising about $5 \%$ medium-sized phenocrysts of olivine and clinopyroxene in a fine-grained holocrystalline groundmass of plagioclase microlaths and clinopyroxene and titanian magnetite granules. The groundmass has a trachytic texture in places. Olivine and clinopyroxene phenocrysts are approximately equal in abundance and generally subhedral. Some olivine phenocrysts are rounded and embayed and contain small glass and chromian spinel inclusions. Clinopyroxene phenocrysts are slightly more rounded than those of olivine and display mottled interior zoning together with thin oscillatory-zoned rims.

The western lava flowed south from a small vent between two cones, at least as far as the southern margin of the plateau, where it has been truncated by erosion. Although also coarsely porphyritic, it is distinct from the eastern lava, with phenocrysts of olivine, clinopyroxene and less abundant titanian magnetite and plagioclase in a holocrystalline basaltic groundmass of plagioclase microlaths and clinopyroxene and titanian magnetite granules. Olivine and clinopyroxene phenocrysts are approximately equal in abundance. Olivine phenocrysts are mostly anhedral; some show thin marginal zoning and many contain small glass and chromian spinel inclusions. Most clinopyroxene phenocrysts are subhedral, although some are partly rounded and deeply embayed. Larger crystals display mottled interior zoning and thin oscillatory-zoned rims. Plagioclase phenocrysts occur as complex laths showing oscillatory zoning.

The young plateau lavas are bounded in many places by flow fronts $1-2 \mathrm{~m}$ high but are truncated sharply elsewhere by rapidly eroding western, southern and eastern margins of the plateau. Moreover, in the centre of the plateau, two of the lavas have north-trending erosional boundaries which face each other across a broad, shallow valley floored by smoothed older lavas overlain in places by volcanolithic moraine. Evidently, a glacier once flowed across the central part of the plateau and truncated the pre-existing lava flows at its margins.

The funnel-shaped pattern formed by moraine ridges on the northeastern side of the plateau, at the head of the postulated glacial valley, also suggests that a glacier once flowed across the plateau and crossed its southern margin on the western side of Cape Lockyer. 
Thepresence of other moraine ridges in the northwestern part of the plateau also indicates the occurrence of wide spread earlier glaciation on the plateau. However, in this area, one of the scoria cones lies over part of one moraine ridge and a young lava flowed down the valley between two ridges. Volcanism therefore postdates glaciation in this part of the plateau.

\section{Lavett Bluff-Cape Labuan}

Basal tic lava of young appearance occurs near sea level on the eastern side of Lavett Bluff, on the south coast, and a blackred basaltic scoria sequence forms the bluff itself a few hundred metres higher. However, no obvious vent has yet been found in the area. The sources of similarly young lavas in the Cape Labuan area are also unknown.

\section{Laurens Peninsula Group}

\section{Mt Dixon}

Laurens Peninsula is about $8.5 \mathrm{~km}$ long $\times 6 \mathrm{~km}$ wide, joined to Big Ben by a high-standing narrow isthmus. At its western end the smaller volcano, Mt Dixon, occurs as a relatively small dome, with its summit about $706 \mathrm{~m}$ a.s.l. and entirely covered by permanent ice. Many young, ropey, blocky and spinose basaltic lavas around its south and west were erupted from small vents low on the flanks. A prominent line of shallow craters occurs on the western flank, including a substantial pit crater and four hornitos at its western end near Cape Cartwright. One of the hornitos is still wellformed, about $2 \mathrm{~m}$ high, $4 \mathrm{~m}$ in diameter and hollow.

The basaltic lavas are underlain on the western and northern sides of Mt Dixon by trachytic lavas. In places, around the coast, particularly behind Macey Cone, the trachytic flows have been truncated by marine erosion, resulting in the formation of low cliffs and terraces over, or against, which some of the basaltic lavas lie. This erosion may have occurred during the most recent sea-level maximum in the southern oceans at about 6000 years BP (Berkman 1992).

Two black lavas of very young appearance lie on the northern and southern flanks of Mt Dixon. They are essentially unvegetated apart from lichen developing on their margins. The northern lava is by far the larger in area and its source appears to be high on the northern side of Mt Dixon. It extends to, and is truncated by, the coastline southwest of Red Island. The southern lava appears to have flowed from a separate vent on the upper southeastern flank of Mt Dixon. It formed two lobes, one of which is truncated by the present coastline. The presence of these youthful lavas, perhaps less than 200 years old, indicates that $\mathrm{Mt}$ Dixon is likely to erupt again in the future. The appearance of most of the other Mt Dixon lavas suggest they may only be a few thousand years old. Some flows on the southern flank are littered with large erratic boulders of trachyte and coarse-grained diorite, suggesting that they are older than the most recent glacial maximum. The most densely vegetated flow occurs east of West Cape. It has a mappable flow front and appears to have been erupted from four or five small vents evenly spaced along the base of an ash ridge about $500 \mathrm{~m}$ long. Ejecta among the ash and vesicular lava bombs include rare chert and limestone clasts, similar to the Laurens Peninsula Limestone exposed about $3 \mathrm{~km}$ to the east, and altered olivine-pyroxene xenoliths.

\section{Red Island}

Red Island is a small ash cone and associated lava field joined to the northwestern tip of Laurens Peninsula by a narrow sandy isthmus with a central lagoon. Only the eastern half of the cone is preserved, the western side having been eroded away by the sea. The western face, the exposed interior of the cone, shows a $2 \mathrm{~m}$ thick trachytic lava concordantly overlain by about $30 \mathrm{~m}$ of ash and breccia. On the northern side of the cone lies the topmost of about 5-6 lava flows that are exposed in section in the sea-cliffs. An older, more vegetated flow lies to the east and south.

\section{Elephant Head-Macey Cone-Cape Cartwright}

The westernmost sector of the Laurens Peninsula coastline contains the substantial ash cones, Elephant Head and Macey Cone, and a series of small lavas and ash cones near Cape Cartwright. Macey Cone is the most prominent feature, comprising an almost complete ash cone $124 \mathrm{~m}$ high with a well-formed, deep summit crater. An associated lava flow emanates from a vent on the southwestern foot of the cone. Immediately along the coast to the northeast of Macey Cone is Elephant Head, which is the remnant of a substantial ash cone apparently similar in size to Macey Cone. It is now largely eroded by the sea but displays a prominent discordant breccia body (the "elephant's trunk") which is interpreted to be a remnant of the crater in-fill breccia.

About a kilometre south around Cape Cartwright are several ash cones and small lava flows. The source of a small ropey lava on the edge of the coast midway between Macey Cone and Cape Cartwright appears to have been seawards of the current coastline, indicating that other young vents in the area may have been eroded away by the sea.

\section{Four Bays Area}

Remnants of vents significantly older than the coast ash cones occur in the area of the isthmus joining Laurens Peninsula to Big Ben, bounded by Atlas Cove, Corinthian Bay, West Bay and Southwest Bay. The largest feature is a circular, columnar-jointed trachytic dome at Cave Bay. It is about $1.5 \mathrm{~km}$ in diameter and its western side has been breached by the sea, resulting in preferential erosion of its centre, such that its northern and southern sides form two ridges which enclose Cave Bay. The top part of the northern ridge, $\mathrm{Mt}$ Andree, is covered by a thick layer of red-black basaltic ash, scoria and lava blocks and bombs, suggesting the presence of a small basaltic vent of young age. Similar material occurs near the summit of Mt Drygalski but without any obvious vent. Mt Aubert de la Rue also appears to be the remnant of a relatively old trachytic vent.

\section{HISTORICAL ERUPTIONS OF HEARD ISLAND}

Flames and fumes on Big Ben were first observed on 2 June 1881 (Aubert de la Rue 1953). On 25 March 1910 a party on the South African sealer Mangaro landed and saw "immense clouds of smoke" issuing from the summit (Anonymous 1910, Neumann van Padang, 1963). Similar observations were made offshore from Wakefield in April 1910 (Aubert de la Rue 1953, Neumann van Padang 1963). Although there was sealing on the island from about 1853 to 1875 and scientific expeditions called at Heard Island in February 1873 (Challenger Expedition - Renard 1889), 
February 1902 (Gauss Expedition), January 1929 (Aubert de la Rue 1929) and November 1929 (BANZARE 19291931 - Mawson 1932), no other volcanic activity is known between the island's first sighting in 1833 and the establish ment of a continuously occupied ANARE station in Decernber 1947 (Tyrrell 1937, Roberts 1950).

Occupation of the research station may have coincided with a major eruptive phase. Station reports (September 1948-December 1954) described frequent emission of steam and smoke from Big Ben (Neumann van Padang 1963). Continuous reporting of activity was impossible because low cloud renders the summit rarely visible from sea level, even in summer. Between January 1950 and February 1952, up to three distinct red glows were observed around the summit, reportedly from at least two distinct vents.

Similar red glows were observed from Marion Dufresne during the nights of 14 January 1985 (Williams \& Duhamel 1986), 1 and 2 October 1985 from Nella Dan, and 4 November 1985 ( from near the ANARE station Burton \& Williams 1986). The Marion Dufresne observations included the sighting of a $200-500 \mathrm{~m}$ long flow which spilled over the summit rim at several places. Observations from Nella Dan indicated two distinct glows. A substantial bluish plume issuing from the summit was also observed during the day following the Marion Dufresne sighting of red glows, on the same day as the ANARE station observation of red glows and later on 17 November from Southwest Bay.

A plume from Heard Island was also observed between 7 October and 3 November by space shuttle astronauts (Bulletin of the Scientific Alert Network 1985). However, while these observations extend from January to November in 1985 , the activity may not have been continuous during this period, as no plume was observed on 25 October and 3 November 1985, although the summit region was fully visible. Several periods of increased seismicity around Heard Island were detected on Kerguelen Island, $466 \mathrm{~km}$ to the northwest, between January and June 1985 (Williams \& Duhamel 1986).

Helicopter flights over Mawson Peak, and a brief landing on its summit, during 1986/87 enabled clear observations of the summit crater and of the 1985 lava flow, including the path of the lava. Despite perfect visibility, no possible vent for the 1950-52 and 1985 eruptive phases other than the summit crater of Mawson Peak was observed, so reports of two or more red glows around the summit must be attributed to magma ponded in the crater and to lava flowing down the flank of Mawson Peak. The latest observed volcanic activity on Heard Island, 7 December 19864 January 1987, consisted of a lava lake at the base of the summit crater, and intermittent and gentle emission of small amounts of bluish smoke and steam. A small explosive emission, resulting in a dark brown stain over the ice surrounding the crater, occurred on 3 January 1987.

A December 181992 earthquake $(M=c .4)$ may have been related to eruption of basalt on Big Ben, rather than to the "McDonald Island pumice source". It is clear that there had been a significant eruption of basalt from the peak on Big Ben forming a flow to the southwest over a horizontal distance of $4.5 \mathrm{~km}$ and vertical elevation of some $1200 \mathrm{~m}$. The flow was approximately $50-100 \mathrm{~m}$ wide and divided into two lobes at an elevation of about $1500 \mathrm{~m}$, approximately $0.5 \mathrm{~km}$ from its terminus. Steam was still evident at the terminus indicating that the flow was not "very old". A message from R. Ledingham, geologist on a tourist ship in the area (minor editorial changes have been made to the original message) stated:

While offshore, we noted that major changes had occurred to the summit cone which had split down about $150 \mathrm{~m}$ in a big wedge and released a double lobed stream of lava to approximately the $1500 \mathrm{~m}$ altitude, heading down towards Cape Arkona on the western side of the Gotley Glacier.

It is possible that lava tubes were feeding lava to the base of the lobes.

Most recently, a plume was reported on 21 December 1996. Possible plumes from the island were identified by observers (N. Young \& A. Tupper, pers. comm., April 1997). It seems in retrospect that these may have been "banner clouds" such as form as atmosphere passes over the top of mountains.

\section{RECENT VOLCANISM ON MCDONALD ISLAND}

Pumice began to wash up on both sides of Elephant Spit on Heard Island in late December 1992, shortly after an earthquake, strong enough to be felt, on 18 December (Dr K. Green, pers. comm., December 1992). Small fragments of the pumice (and krill and penguin feathers) clogged the water intake of MV Icebird, which had to be cleaned to allow the ship to proceed. Four specimens, collected from Heard Island beaches, were analysed. A small, grey boulder from higher elevation than the others differed in composition and origin. It matched material collected in 1963 from "flotsam north of Heard Island" (Stephenson 1964), related to vast rafts of pumice released in the South Atlantic Ocean during the eruption in the South Sandwich Islands area in 1962 (Gass et al. 1963). This is probably the same material referred to by Dr Phillip Law (pers. comm., 19 August 1993) who saw rafts of pumice near Heard Island in January 1963. Stephenson (1972) presented an analysis (no. 54) of this material. The rock type is dacite characterised by relatively high silica $\left(66.7 \% \mathrm{SiO}_{2}\right.$ in the analysed sample) and high $\mathrm{Na}_{2} \mathrm{O} / \mathrm{K}_{2} \mathrm{O}$, resulting in plagioclase being dominant over orthoclase feldspar.

The other three samples have a quite different composition, unlike any lavas so far known from Heard Island. They are khaki-green colour and resemble McDonald Islands lavas (J. Sheraton, pers. comm., 10 June 1993). They indicate a submarine eruption but the source was not identified. Green also referred to the smell of sulphur gases, suggestive of a recent volcanic source and thus eruption. The volcanic rocks of Heard Island have been the subject of quite extensive study over many years by Tyrrell (1937), Stephenson, Nicholls, Clarke, Barling and Wheller, and their composition, distribution and source are thus reasonably well known. The rock type in the three specimens is phonolite, characterised by lower silica $54.6 \% \mathrm{SiO}_{2}$ in these samples, very high alkalies $\left(\mathrm{Na}_{2} \mathrm{O}+\mathrm{K}_{2} \mathrm{O}\right)$. They are particularly enriched in $\mathrm{Na}_{2} \mathrm{O}(10.9-11.3 \%)$, Ga, $\mathrm{Nb}$, Ta and $\mathrm{Zr}$, but relatively low in $\mathrm{MgO}, \mathrm{CaO}, \mathrm{Ba}$ and $\mathrm{Sr}$. Phonolites from the $\mathrm{McD}$ onald Islands include fractionated types of similar compositions to the pumice samples (Clarke et al. 1983). Analyses of the fresh pumice stranded on Heard Island suggest it evolved over a long time in a magma chamber before eruption (Collerson et al. 1998). 
Steam emission at the northern end of McDonald Island was seen from RSV Aurora Australis on 18 March 1997, at a distance of about $4 \mathrm{~km}$. Steam arose from several sites, in the form of small clouds which moved quickly and seemed to come from a series of vents across the northern end of the island between The Needle and Macaroni Hill, north of Samarang Hill. Large quantities of volatiles were being emitted from a number of point sources and one fissure system on a large pile of apparently loose debris. The presence of steam and debris suggested that a volcanic eruption had recently occurred. The day was still and there was low cloud but visibility was quite good. There had been no reported eruption from the island before. The interpretation was strengthened by the 1992 reports of pumice on Heard Island beaches (Quilty 1995).

Since the initial sighting, $\mathrm{Mr} \mathrm{R}$. Williams (pers. comm., 2 April 1997) was on the FV Austral Leader on 2 April and saw evidence of extensive steam activity on McDonald Island from $25-30 \mathrm{~km}$. He reported much vapour on a day when there was clear blue sky with only a small amount of medium and high-altitude cloud. The ship circumnavigated the island at 3-4 km and observed many "steam/smoke" clouds rising from the summit and flanks of the northern and middle parts of the island. Reports also referred to small black lava flows but, due to the amount of steam and cloud, it was difficult to tell whether the apparent activity was due to local fumaroles at roughly sea level or to lava flows descending gullies from higher altitude. The summit of the mid part of the island, which was the centre of the steam emission, had a clear ring of yellow-green deposit around it, which Williams took to be sulphur. No lava was seen being ejected into the air, nor were there any red glows. There was no evidence of volcanic activity on the southern part of the island. Wildlife was there in abundance and showed no sign of concern. Scientists on board another fishing vessel, FV Pakura, on 24 April also saw the steam plumes, and made videos and took photographs of the event. The Bulletin of the Global Volcanism Network (1999) carried a report for 1999 from scientists on board JOIDES Resolution for the Ocean Drilling Program.

\section{GEOLOGICAL SIGNIFICANCE OF HEARD ISLAND}

Heard and the McDonald Islands are young oceanic-island volcanoes which, together with the Kerguelen Islands $466 \mathrm{~km}$ to the northwest, are the only subaerial expressions of the dominantly volcanic and relatively shallow northern part of the submarine Kerguelen Plateau which has a geological history extending over $115 \mathrm{Ma}$ (Davies et al. 1989). The geological histories of Heard and the Kerguelen Islands extend over the last $50 \mathrm{Ma}$ while the McDonald Islands are very young, perhaps having formed within the last 100000 years.

The geochemical compositions and mineralogy of the volcanic rocks from Heard Island and the McDonald Islands indicate they belong to the oceanic-island type of modern volcanoes, similar to many other Subantarctic islands, such as Kerguelen, St Paul, Amsterdam, Marion, Crozet, Bouvet, Tristan da Cunha and Gough Island (Tyrrell 1937, Lambeth 1952, Stephenson 1972, Clarke et al. 1983, Barling et al. 1994). This type of volcano is generally regarded as having formed as a result of plumes, or hotspots, which originate from over $600 \mathrm{~km}$ deep within the earth.
The Heard Island lavas have been recognised as two separate volcano-magmatic lineages, the basanitic to trachytic Laurens Peninsula Series (LPS) and the Big Ben Series (BBS) (Wheller \& Barling 1992, Barling et al. 1994). The BBS contain relatively evolved basalts and trachybasalts as well as more primitive basanites formed by accumulation of olivine and clinopyroxene phenocrysts. Overall, the LPS appear to have formed by relatively simple, closed-system fractional crysallisation processes while the BBS seem to have experienced a more dynamic, mixing-controlled magmatic environment.

The two groups also display significant $\mathrm{Sr}, \mathrm{Nd}$ and $\mathrm{Pb}$ isotope differences, with the LPS displaying more mantlelike characteristics. Helium isotope ratios also indicate separate origins, with the BBS having low MORB- and crust-like ${ }^{3} \mathrm{He} /{ }^{4} \mathrm{He}$ values of $0.4-8.4$, while the LPS possesses "deep-mantle" values of 16.2-18.3 (Hilton et al. 1995).

The McDonald Island lavas are distinct from those of Heard Island by having phonolitic compositions, although their $\mathrm{Sr}$ and $\mathrm{Nd}$ isotopic values are similar to those of the RBS (Clarke et al. 1983, Barling et al. 1994). It seems unlikely that phonolites have been erupted from Heard Island; none were found among the numerous analyses reported by Barling et al. (1994), and those described by Tyrrell (1937) from Atlas Cove may well have been pumice clasts washed ashore following eruption from the McDonald Islands.

In general, the Heard Island volcanics cover the widest range of isotopic compositions known from any shortlived oceanic-island volcano system. The LPS possess a restricted range of compositions similar to those of other oceanic island volcanoes in the central Indian Ocean and suggestive of a deep mantle source. However the BBS cover a much wider range, which is similar to that of Kerguelen Island, more MORB- and crust-like in character, suggesting an origin in which very shallow mantle and crustal processes were important.

Heard Island and the McDonald Islands have been related to the broad-scale geological evolution of the Indian Ocean through their compositional, isotopic and temporal associations with other volcanic and submarine topographic features in the Indian Ocean, such as the Kerguelen Islands, the Kerguelen, Broken and Naturaliste Plateaux, and Ninetyeast Ridge, as well as the Rajmahal and Sylhet Traps in India and the Bunbury Basalt of southwestern Australia (Duncan 1978, Storey et al. 1988,1989, Davies et al. 1989, Weis et al. 1989, 1991, Barling et al. 1994). In general, this evolution implies the existence of a near-stationary mantle plume beneath the current Kerguelen Plateau for the last 135 million years, during which time about $60-120$ million $\mathrm{km}^{3}$ of basalt was generated as first India and then Australia separated from Antarctica to form the Indian Ocean basin (Davies et al. 1989).

There is debate, however, about the significance and role of the Heard and McDonald magmatism. Barling et al. (1994) suggested that Heard Island and the Quaternary volcanism of the Kerguelen Islands represent contemporaneous volcanism derived from the same large plume, as opposed to earlier proposals by others that Heard Island represents the latest manifestation of the plume. They also argued that the volcanic rocks of the BBS are the major products of the plume, with the plume-derived magma having been locally mixed with a high ${ }^{87} \mathrm{Sr} /{ }^{86} \mathrm{Sr}$, low ${ }^{206} \mathrm{~Pb} /{ }^{204} \mathrm{~Pb}$ component which ultimately may have been sediment subducted into the mantle during the Proterozoic 
prior to the formation of Gondwana. They further suggest that the LPS rocks represent a local mobilisation of lithospheric mantle which had been enriched as a result of earlier plume activity.

An alternative view is that the LPS derived from the plume, essentially free of any lithospheric interaction apart from shallow fractional crystallisation, and the BBS represent plume-derived magma which has been significantly contaminated by lithospheric mantle, retaining isotopic and incompatible trace element characteristics of Gondwana subcontinental mantle. This is mainly suggested by the high plume-like ${ }^{3} \mathrm{He} /{ }^{4} \mathrm{He}$ values of the LPS and the low, lithosphere-like values for the BBS revealed by Hilton $e t a l$. (1995). It is also consistent with the distribution of BBS Sr, $\mathrm{Nd}$ and $\mathrm{Pb}$ isotopic compositions between the plume source represented by the LPS and the Gondwana subcontinental lithosphere represented by ultrapotassic lavas from Gaussberg (Collerson \& McCulloch 1983, Taylor et al. 1984).

In this case, the close isotopic similarities between the BBS and the Kerguelen lavas point to a significant role for lithospheric contamination in the formation of ocean island lavas, and the retention of subcontinental characteristics in otherwise "oceanic" lithospheric mantle long after continental dispersement has occurred. Moreover, it is important to note that this model does not require the presence of actual upper continental crust as part of the Kerguelen Plateau, as proposed by Watkins et al. (1974). It requires only the remains of continental lithospheric mantle, and this may be an expected consequence of the dispersal of the Antarctic, Indian and Australian continents away from the area in which the Kerguelen Plateau now lies.

Finally, while otherwise very similar in major and trace elements, the Heard Island lavas, particularly the LPS, possess unusually high levels of $\mathrm{TiO}_{2}$ compared to other ocean island volcanic suites (Stephenson 1972). This is not only a fractionation effect, as the most primitive basanites also have high $\mathrm{TiO}_{2}$, and must be inherited from the source. If the LPS does represent the uncontaminated plume source then its high- $\mathrm{TiO}_{2}$ character may suggest that it is a relatively fertile plume and, therefore, not directly related to the long-lived and presumably now relatively depleted plume which gave rise to the broad-scale evolution of the Kerguelen Plateau.

\section{ACKNOWLEDGEMENTS}

The authors thank Drs M.R. Banks and P. Selkirk for the invitation to make this summary. June Pongratz drew the figures. We thank Drs J. Stephenson and F.L. Sutherland for their reviews that led to considerable improvement in this paper.

\section{REFERENCES}

ANonymous, 1910: Wiedererwachen der vulkanischen Tätligkeit auf der Heard Insel. Zeit. d. Ges. f. Erdk.: 529.

Aubert de la Rue, E., 1929: Sur la constitution géologique de l'Isle Heard. Compte Rendu Acad. Sci. Paris 189(3): 219231.

Aubert DE la Rue, E., 1953: LES TERRES AUSTRALES. QUE SAIS-JE? Presses Universitaires de France, Paris: 83-88.
Barling, J., 1990a: The petrogenesis of the Newer Lavas of Heard Island, southern Indian Ocean. Unpubl. PhD thesis, Monash University: 248 pp. plus appendices.

BARLING, J., 1990b: Heard and McDonald Islands. In LeMasurier, W.E. \& Thomson, J.W. (Eds): VOLCANOES OF THE ANTARCTIC PLATE AND SOUTHERN OCEANS. Antarctic Res. Ser. 48: 435-441.

BARLING, J. \& GoldSTEIN, S.L., 1990: Extreme isotopic variations in Heard Island lavas and the nature of mantle reservoirs. Nature 348: 59-62.

Barling, J., Goldstein, S.L., Wheller, G.E. \& Nicholls, I.A., 1988: Heard Island: an example of large isotopic variations on a small oceanic island. Chem. Geol. 70: 46.

Barling,J., Goldstein,S.L. \& Nicholls,I.A., 1994: Geochemistry of Heard Island (southern Indian Ocean): characterization of an enriched mantle component and implications for enrichment of the sub-Indian Ocean mantle. J. Petrol. 35: 1017-1053.

Berkman, P.A., 1992: Circumpolar distribution of Holocene marine fossils in Antarctic beaches. Quat. Res. 37: 256260.

BudD, G.M., 2000: Changes in Heard Island glaciers, king penguins and fur seals since 1947. Pap. Proc. R. Soc. Tasm. 133(2): 47-60.

Bulletin of the Global Volcanism Network, 1999: 24(1): 9.

Bulletin of the Scientific Alert Network, 1985: 10(10): 11 .

Burton, H.R. \& Williams, R.L., 1986: ANARE Heard Island Report 1985/86. Australian Antarctic Division, Kingston (unpubl.).

Clarke, I., 1982: Report on geology. In Veenstra, C \& Manning, J. (Eds): Expedition to the AustralianTerritory of Heard and McDonald Islands 1980. Tech. Rep. Div. Nat. Mapping Canberra: 46-51.

Clarke, I., McDougall, I. \& Whitford, D.J., 1983: Volcanic evolution of Heard and McDonald Islands, southern Indian Ocean. In Oliver, R.L., James, P.R. \& Jago, J.B. (Eds): ANTARCTIC EARTH SCIENCE. Australian Academy of Science, Canberra: 631-635.

Collerson, K.D. \& McCulloch, M.T., 1983: Nd and Sr isotope geochemistry of leucite-bearing lavas from Gaussberg, East Antarctica. In Oliver, R.L., James, P.R. \& Jago, J.B. (Eds): ANTARCTIC EARTH SCIENCE. Australian Academy of Science, Canberra: 676-680.

Collerson, K.D., Regelous, M., Frankland, R., Wendt, J.I. $8 x$ WHeLleR, G., 1998: 1997 eruption of McDonald Island (Southern Indian Ocean): new trace element and Th-Sr$\mathrm{Pb}-\mathrm{Nd}$ isotopic constraints on Heard-McDonald Islands magmatism. Geol. Soc. Aust. Abst. Ser. 49: 87.

Davies, H.L., Sun, S.-S., Frey, F.A., Gautyer, I., McCulloch, M.T., Price, R.C. Bassias, Y., Klootwijk, C.T. \& LECLAIRE, L., 1989: Basalt basement from the Kerguelen Plateau and the trace of a Dupal plume. Contrib. Mineral. Petrology 103: 457-469.

DUNCAN, R.A., 1978: Geochronology of basalts from the Ninetyeast Ridge and continental dispersion in the eastern Indian Ocean. J. Volcanol. Geotherm. Res. 4: 283-305.

FitzGerald, P., 1999: Cretaceous-Cenozoic Tectonic evolution of the Antarctic Plate. Terra Antart. Rep. 3: 109-130.

Fleming, C.A., 1957: A new species of fossil Chlamys from the Drygalski Agglomerate of Heard Island, Indian Ocean. J. Geol. Soc. Aust. 4: 13-19.

Francis, J.E. \& Coffin, M.F., 1992: Cretaceous fossil wood from the Raggatt Basin, southern Kerguelen Plateau (Site 750). Sci. Res., Ocean Drilling Program 120: 273-280.

Gass, I.G., Harris, P.G. \& Holdgate, M.W., 1963: Pumice eruption in the area of the South Sandwich Islands. Geol. Mag. 100: 321-330.

Hilton, D.R., Barling, J. \& Wheller, G.E., 1995: Effect of shallow-level contamination on the helium isotope systematics of ocean-island lavas. Nature 373: 330-333. 
Irving, E., Stephenson, P.J. \& Major, A., 1965: Magnetism in Heard Island rocks. J. Geophys. Res. 70: 3421-3427.

LAMBETH A.J., 1951: Heard Island. Geography and glaciology. J. Proc. R. Soc. NSW 84(2): 92-98.

LAMBETH A.J., 1952: A geological account of Heard Island. J. iroc. R. Soc. NSW 86(1): 14-19.

MAWSON D., 1932: The B.A.N.Z. Antarctic Research Expedition, 1929-31. Geogr. J. 80: 105-106.

MoHr, B.A.R. \& GeE, C.T., 1992: An Early Albian palynoflora from the Kerguelen Plateau, southern Indian Ocean (Leg 120). Sci. Res. Ocean Drilling Program 120: 255-271.

Munschy, M., Dyment, J., Boulanger, M.O., Boulanger, D., Trssot, J.D., Schlich, R., Rotstein, Y. \& Coffin, M.F., 1992: Breakup and seafloor spreading between the Kerguelen Plateau-Labuan Basin and the Broken RidgeDiamantina Zone. Sci. Res. Ocean Drilling Program 120: 931-944.

Neumann van Pandang, M., 1963: Catalogue of THE ACTIVE VOLCANOES OF THE WORLD. VOL. 16. ARABIA AND THE INDIAN OCEAN. International Association of Volcanologists, Rome: 1-64.

Nougier, J. \& Thomson, J.W., 1990: Isles Kerguelen. In Le Masurier, W.E. \& Thomson, J.W. (Eds): VOLCANOES OF THE ANTARCTIC PLATE AND SOUTHERN OCEANS. Antarct. Res. Ser. 48: 429-434.

Philippl, E., 1908: Geologie der Herd Insel. Dtsch Südpolar Exped. 1901-1903, 11 (3): 241-250.

QuilTY, P.G., 1995: Heard Island: Offshore McDonald Islands. Bull. Volcan. Eruptions 32: 32, 127.

Quilty, P.G., Shafik, S., McMinn, A., Brady, H. \& Clarke, I., 1983: Microfossil evidence for the age and environment of deposition of sediments on Heard and McDonald Islands, In Oliver, R.L., James, P.R. \& Jago, J.B. (Eds): ANTARCTIC EARTH SCIENCE, Australian Academy of Science, Canberra: 636-639.

Reinisch, R., 1908: Gesteine der Heard Insel. Dtsch Südpolar Exped. 1901-1903, 2: 251-263.

Renard, A.F., 1889: Reports on petrology of oceanic islands. Sci. Res., HMS "Challenger" Phys. Chem. 2: 142.

Roberts, B., 1950: Historical notes on Heard and McDonald Islands. Polar Rec. 5: 580-584

Royer, J.-Y. \& Coffin, M.F., 1992: Jurassic to Eocene plate tectonic reconstructions in the Kerguelen Plateau region. Sci. Res., Ocean Drilling Program 120: 917-928.

Ruddell, A. \& Allison, I., 1997: The sensitivity of glaciers at Heard Island to change, and their recent response. (Abstract). Proceedings of 1997 Joint Assemblies of the
International Association of Meteorology and Atmospheric Sciences and International Association for Physical Sciences of the Oceans, Melbourne.

SCHLICH, R., Wise, S.W. JR. ET AL., 1989: INIT. REP. OCEAN DRILLING PROGRAM 120.648 pp.

STEPHENSON, P.J., 1964: Some geological observations on Heard Island. In Adie, R.J. (Ed.): ANTARCTIC GEOLOGY. North Holland, Amsterdam: 14-24.

Stephenson, P.J., 1972: Geochemistry of some Heard Island igneous rocks. In Adie, R.J. (Ed.): ANTARCTIC GEOLOGY AND GEOPHYSICS. Universitetsforlaget, Oslo: 793-801

Storey, M., Saunders, A.D., Tarney, J., Leat, P., Thirwell, M.F., Thompson, R.N., Menzies, M.A. \& Marriner, G.F., 1988: Geochemical evidence for plume-mantle interactions beneath Kerguelen and Heard Islands. Nature 336: 371-374.

Storey, M., Saunders, A.D., Tarney, T., Gibson, I.L., Norry, M.J., Thirlwell, M.F., Leat, P., Thompson, R.N. \& MenzIES, M.W., 1989: Contamincation of Indian Ocean asthenosphere by the Kerguelen-Heard mantle plume. Nature 338: 574-576.

Taylor, H.P., Turi, B. \& Cundari, A., 1984: $18 \mathrm{O} / 16 \mathrm{O}$ and chemical relationships in $\mathrm{K}$-rich volcanic rocks from Australia, East Africa, Antarctica and San VernanzoCupaello, Italy. Earth Planet. Sci. Lett. 69: 263-276.

Tyrell, G.W., 1937: The petrology of Heard Island. Rep BANZ Antarctic Research Expedition, ser. A, 2. 29-56.

WatKins, N.D., GunN, B.M., NougIer, J. \& BAKSI, A.K., 1974: Kerguelen: continental fragment or oceanic island? Bull. Geol. Soc. Am. 85: 201-212.

Weis, D., Bassias, Y., Gautier, I. \& Mennessier, J.-P., 1989: Dupal anomaly in existence $115 \mathrm{Ma}$ ago: evidence from isotopic study of the Kerguelen Plateau (south Indian Ocean). Geochem. Cosmochim. Acta 53: 2125-2131.

Weis, D., Frey, F.A., Saunders, A., Gibson, I. And Leg 121 Scientific Shipboard Party, 1991: Ninetyeast Ridge (Indian Ocean): a $5000 \mathrm{~km}$ record of a Dupal mantle plume. Geology 19: 99-102.

WheLleR, G.E. \& BarLING, J., 1992: Distribution, geochemistry and origins of the youngest lavas of Heard Island, southern Indian Ocean. 11th Australian Geological Convention (Ballarat). Geol. Soc. Aust Abstr. 32: 203-204.

Williams, R. \& Duhamel, W.G., 1986: Volcanic activity on Heard Island. Polar Rec. 23: 88-90.

(accepted 1 February 2000) 